\title{
Dynamics of key plant nutrients (N \& P) in hokersar, a typical wetland of Kashmir Himalaya, India
}

Javaid Ahmad Shah ${ }^{1 *}$, Ashok K. Pandit ${ }^{1}$ and G. Mustafa Shah ${ }^{2}$

*Correspondence: javaidshah31@gmail.com

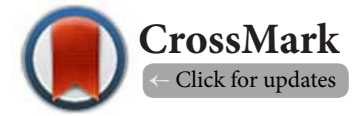

${ }^{1}$ Centre of Research for Development (CORD), University of Kashmir, Srinagar-190006, J \& K, India.

${ }^{2}$ Department of Zoology, University of Kashmir, Srinagar-190006, J \& K, India.

\begin{abstract}
Hokersar wetland suffers highly due by nutrient inputs from the catchment area, internal wetland processes and various types of anthropogenic pressures around. To characterize nutrient dynamics of the wetland, nitrogen $(\mathrm{N})$ and phosphorus $(\mathrm{P})$ samples were collected from six study sites in the Queen wetland of Kashmir Himalaya for a period of one year from Sep. 2012 to Aug. 2013. Clear spatial and temporal variations were observed among the recorded parameters (ammonical nitrogen, nitrate nitrogen, total orthophosphate phosphorus and total phosphorus) throughout the year. Ammonical nitrogen concentration was found to be maximum in winter $(242.3 \pm 10.1 \mu \mathrm{g} / \mathrm{L})$. Lower nitrate nitrogen was observed in summer, recording $259.6 \pm 35.3 \mu \mathrm{g} / \mathrm{L}$. Both the forms of phosphorus registered higher values in summer and lower values in winter. Scatter plot showed highly significant values among all the parameters $\left(\mathrm{R}^{2}=0.748\right.$ and 0.719). Principal component analysis showed highest principle component vector displacement among the sites IV and VI reflecting polluted nature of the sites. Further, higher Eigen-vector displacement values were due to ammonical nitrogen and nitrate nitrogen, registering values 3.36724 and 0.542639 respectively. Similarity matrix was highest between total phosphorus and ammonical nitrogen (92.9666\%), followed by ammonical nitrogen and nitrate nitrogen making 58.5729\%.
\end{abstract}

Keywords: Wetland, nutrient dynamics, eutrophication, macrophytes, principle component analysis

\section{Introduction}

Wetlands are reported to act as sources [1], sinks [2] or as transformers of inorganic forms into organic forms of nutrients $[3,4]$ which largely depend upon the wetland type and the hydrological condition of the wetland $[5,6]$. Eutrophication as a result of excessive nutrient loading results in high primary production (weed infestation and algal blooms) is one of the most important and extensive water quality problems at global level. Wetlands, representing the most productive ecosystems in the world are thus usually dominated by aquatic macrophytes [7] and the aquatic vegetation in wetland ecosystems is in turn governed by the availability of nutrients particularly nitrogen and phosphorus $[8,9]$.

Wetlands occupy about $7 \%$ of the earth's land surface $[10,11]$. However; wetlands in the world are degrading at an accelerated rate, more than other ecosystems critically disturbing their biodiversity. Due to their fast squeezing rate, some of the permanent wetlands have been transformed into semipermanent or temporary wetlands with groundwater table falling down rapidly [12]. Lakes and wetlands, located in areas with exhaustive agriculture, are being gradually enriched with nitrogen and phosphorus, resulting in eutrophication of these shallow habitats [13], causing increase in their productivity [14]. In recent past three to four decades majority of the wetlands have undergone gradual to exhaustive eutrophication, mainly through human intervention, agricultural runoff and waste water from the catchment, causing degradation of both physical as well as biological systems [15-18]. Shallow inland lakes, particularly susceptible to eutrophication because their productivity can respond rapidly to nutrient enrichment and even reduction in external P loading; often fail to improve water quality because of internal $P$ regeneration from the sediments [19-22]. In freshwater ecosystems the source of nutrients is generally from organic matter of plants that undergo mineralization and atmospheric nitrogen fixed by aquatic plants and $\mathrm{P}$ as associated with apatite bearing minerals $[\mathbf{2 3}, \mathbf{2 4}]$. However, anthropogenic activities are increasing throughout the world $[25,26]$ at an alarming pace that greatly exceed natural $\mathrm{N}$ and 
Shah et al. Journal of Environmental Engineering \& Ecological Science 2015,

P for these aquatic ecosystems [27].

Various authors are of the view that permanent and seasonal changes within wetlands occur in response to a range of external factors, such as the changes in the land systems at the catchment scale [28-30], fluctuations in water table [31], climate change [32], besides other human activities [33]. Generally, wetlands are known to function as biofilters in hydrologic systems [34], besides retaining and transferring nutrients ( $\mathrm{N}$ and $\mathrm{P}$ ) from aquatic ecosystems [35]. They have been used as wastewater treatment plants to reduce pollution in nearby lakes and rivers [36] and are known to play significant role in carbon sequestration [32]. The earlier studies conducted on Hokersar were made by investigators like Kaul and Zutshi [37]; Handoo [38]; Handoo and Kaul [39]; Kak [40]; Kaul [41]; Pandit [42]; Khan [43]; Rather et al., [44]; Pandit and Kumar [45] and Kumar and Pandit [46], but most of these pertain to biological parameters. Till date very little published information is available in terms of spatiotemporal changes in dynamics of key plant nutrient [nitrogen and phosphorus] in Hokersar, the Queen of wetlands in Kashmir Himalaya having a tremendous socio-economic value.

\section{Study area}

Hokersar a natural perennial wetland $\left(34^{\circ} 05^{\circ} \mathrm{N}-34^{\circ} 06^{\top} \mathrm{N}\right.$ latitude and $74^{\circ} 8-74^{\circ} 12^{\circ} \mathrm{E}$ longitude) situated $10 \mathrm{~km}$ to the west of Srinagar on Srinagar-Baramullah Highway in the northern most part of Doodhganga catchment. The wetland, designated as Ramsar Site in 2005 is spread over an area of $7.5 \mathrm{~km}^{2}$ situated at an altitude of $1,584 \mathrm{~m}$ (amsl). The wetland harbours about five million migratory waterfowl during winter that migrate from Siberia and the Central Asian region. The wetland is fed by two inlet streams, Doodhganga [from east] and Sukhnag Nalla [from west]. The wetland attains a maximum depth of $2.5 \mathrm{~m}$ in spring due to appreciation in discharge from the snow-melt water in the upper reaches of Doodhganga catchment. Minimum water depth $(0.7 \mathrm{~m})$ was recorded in autumn [45]. The excess water is drained out through an outlet gate known as Needle- Gate on north-west of the wetland near the village Sozieth, having a weir and lock system, which regulates the water level to provide a better habitat for migratory waterfowl during winter.

\section{Material and methods}

Water samples were collected on monthly basis and the results were interpreted on seasonal basis. The analysis was carried out as per the standard of APHA, [47] and Wetzel and Likens, [48]. Color intensity was measured at $640 \mathrm{~nm}$ (ammonical nitrogen), $410 \mathrm{~nm}$ (nitrate nitrogen), $690 \mathrm{~nm}$ (ortho as well as for total-phosphate phosphorus), using Systronics-116 spectrophotometer modal. Among the six sites, three sites (II, III and IV) were located in the open water area having mostly submerged macrophytic growth while the remaining three sites $(\mathrm{I}, \mathrm{V}$ and $\mathrm{VI})$ were distributed in the rest of the wetland. Site I is located near the entry site of Doodhganga into the lake near Hajibagh. Sites II and III have well developed macrophytic growth with little anthropogenic pressure. Site IV is located near the Zainakut area having anthropogenic pressure due to human interference. Site $\mathrm{VI}$ is located near the outlet of the wetland called Sozieth having direct influence of human as well as animal habitation (Figure 1). Statistical analysis was carried out by SPSS version 16 and PAST.

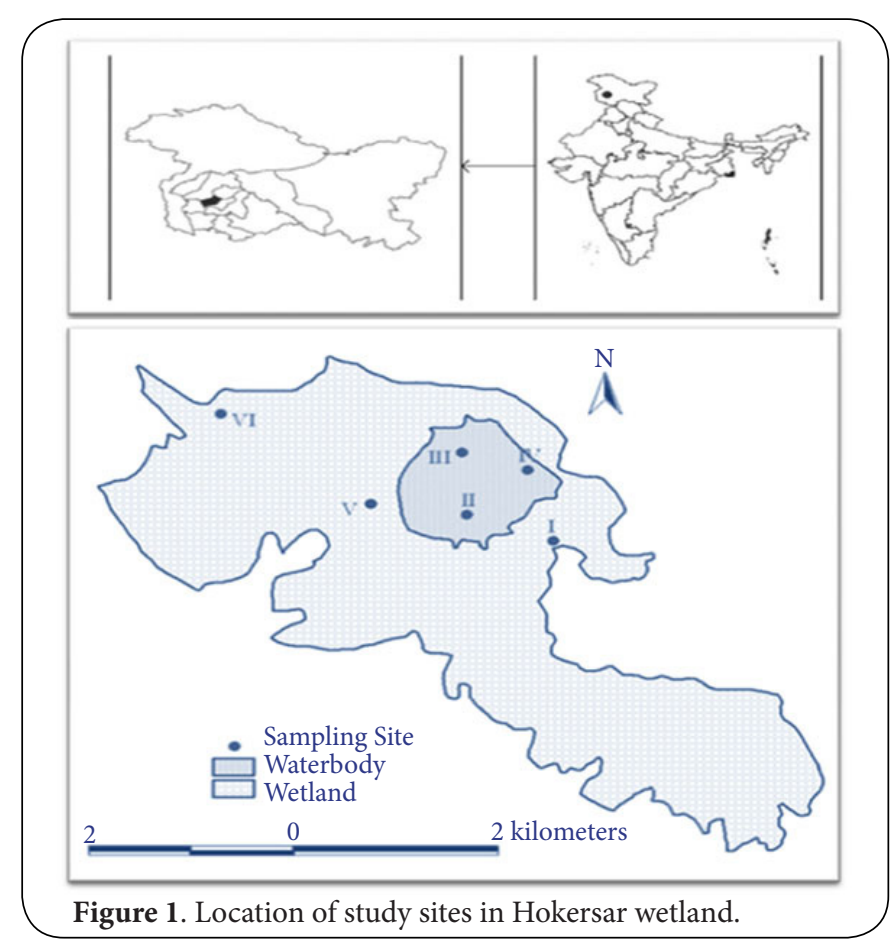

\section{Results and discussion}

Major nutrients like nitrogen $(\mathrm{N})$ and phosphorus $(\mathrm{P})$ are crucial and are required to a large extent to support a variety of cell physiological functions [49]. These nutrients limit primary production especially in freshwater ecosystems [50,51]. Bioavailability of these nutrients in aquatic ecosystems varies among living organisms which mostly comprises of dissociated orthophosphate ions $\left(\mathrm{H}_{2} \mathrm{PO}_{4}, \mathrm{HPO}_{4}{ }^{2-}\right.$ and $\left.\mathrm{PO}_{4}{ }^{3-}\right)$ in the case of $\mathrm{P}$ [52] and nitrite $\left(\mathrm{NO}_{2}{ }^{-}\right)$, nitrate $\left(\mathrm{NO}_{3}{ }^{-}\right)$and ammonium $\left(\mathrm{NH}_{4}{ }^{+}\right)$ ions in the case of $\mathrm{N}$ [24]. Bottom-up control by phytoplankton also equally influences $\mathrm{N}$ and $\mathrm{P}$, indicating co-limitation in aquatic ecosystems [53]. During the entire study period, distinct spatial and temporal variation were observed in ammonical nitrogen $\left(\mathrm{NH}_{4}-\mathrm{N}\right)$ concentration which varied from a minimum of $116.2 \pm 18.8 \mu \mathrm{g} / \mathrm{L}$ in summer to a maximum of $242.3 \pm 10.1$ $\mu \mathrm{g} / \mathrm{L}$ in winter (Figure 2). In autumn the mean concentration was $181.2 \pm 24.8 \mu \mathrm{g} / \mathrm{L}$ with a minimum of $167 \pm 28.2 \mu \mathrm{g} / \mathrm{L}$ at site III and a maximum of $202 \pm 31 \mu \mathrm{g} / \mathrm{L}$ at site IV. Nitrate nitrogen $\left(\mathrm{NO}_{3}-\mathrm{N}\right)$ concentration maintained a wide range fluctuating between $226.3 \pm 52.5 \mu \mathrm{g} / \mathrm{L}$ and $631.3 \pm 29.1 \mu \mathrm{g} / \mathrm{L}$. Lower values for the anion were observed in summer $259.6 \pm 35.3 \mu \mathrm{g} / \mathrm{L}$, where as higher values were registered in winter recording 


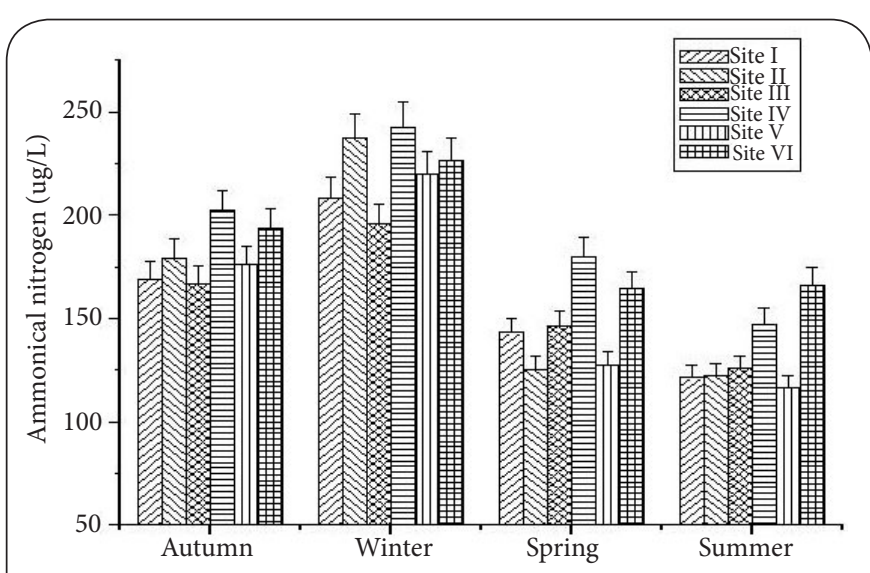

Figure 2. Seasonal variations of ammonical nitrogen $(\mu \mathrm{g} / \mathrm{L})$ at six study sites.

$570.6 \pm 51.5 \mu \mathrm{g} / \mathrm{L}$ (Figure 3). Orthophosphate phosphorus (OPP) varied from $50.7 \pm 8.1 \mu \mathrm{g} / \mathrm{L}$ during winter at site $V$ to $165.3 \pm 21.1 \mu \mathrm{g} / \mathrm{L}$ during summer at site IV. In general maximum concentration of OPP were registered in summer (140.4 \pm 16 $\mu \mathrm{g} / \mathrm{L})$, followed by spring (106.9 $\pm 18.8 \mu \mathrm{g} / \mathrm{L})$, autumn $(71.3 \pm 5.7$ $\mu \mathrm{g} / \mathrm{L})$ and decreasing to a minimum in winter $(61.1 \pm 11 \mu \mathrm{g} / \mathrm{L})$ (Figure 4). Total phosphate phosphorus (TPP) depicted a trend to similar that of OPP. Here again greater mean values of TPP were maintained in summer registering $236.2 \pm 13.6 \mu \mathrm{g} / \mathrm{L}$ against the lower being registered for winter $(151.2 \pm 15 \mu \mathrm{g} / \mathrm{L})$ (Figure 5). Scatter plots showed highly significant correlation $\left(R^{2}=0.748\right.$ and 0.719$)$ within parameters (Figures 6 and 7 ).

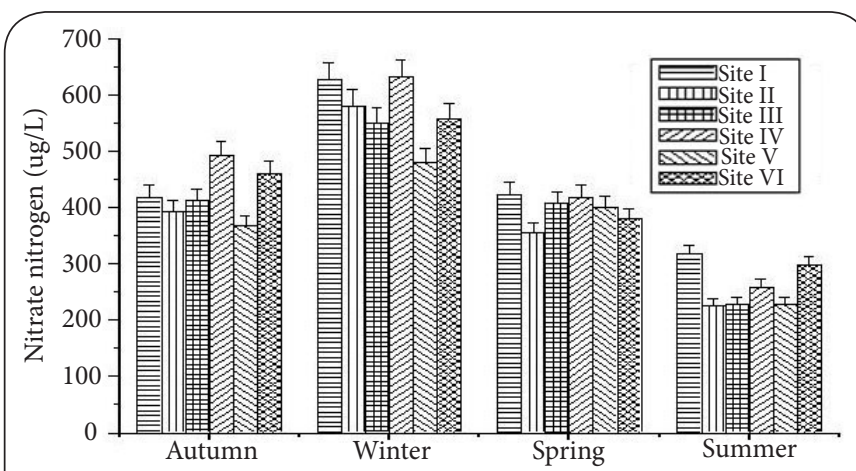

Figure 3. Seasonal variations of nitrate nitrogen $(\mu \mathrm{g} / \mathrm{L})$ at six study sites.

Surplus input of $\mathrm{N}$ and $\mathrm{P}$ to waters is the major cause of eutrophication that degrades the water quality and ecological integrity of the systems [54-56]. Ammonical nitrogen is generated by heterotrophic bacteria as the primary end product of decomposition of organic matter and is readily assimilated by plants [57]. The lower concentrations of ammonical nitrogen and nitrate in summer can be attributed mainly due to sequestration by phytoplankton [58]. Higher concentrations of nitrate were recorded in winter, followed by

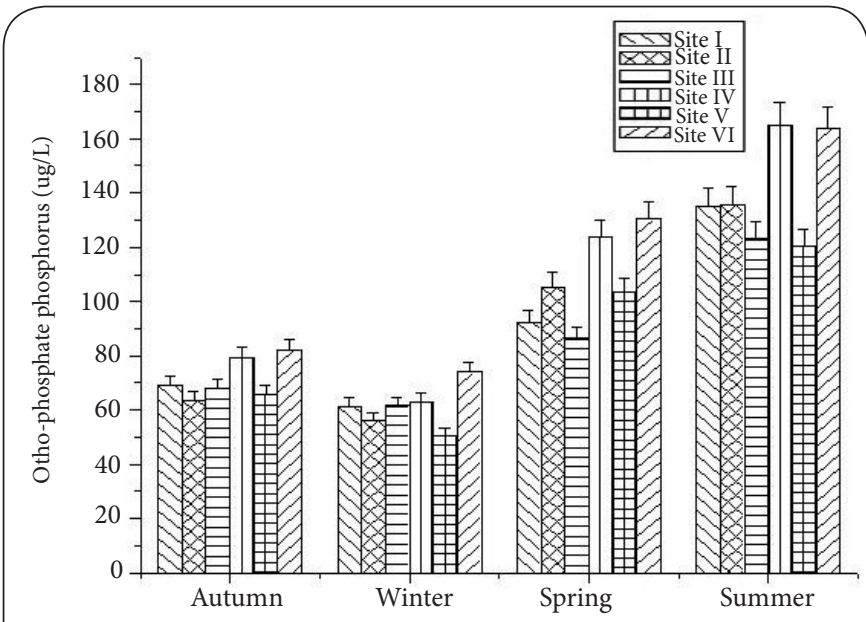

Figure 4. Seasonal variations of ortho-phosphate phosphorus $(\mu \mathrm{g} / \mathrm{L})$ at six study sites.

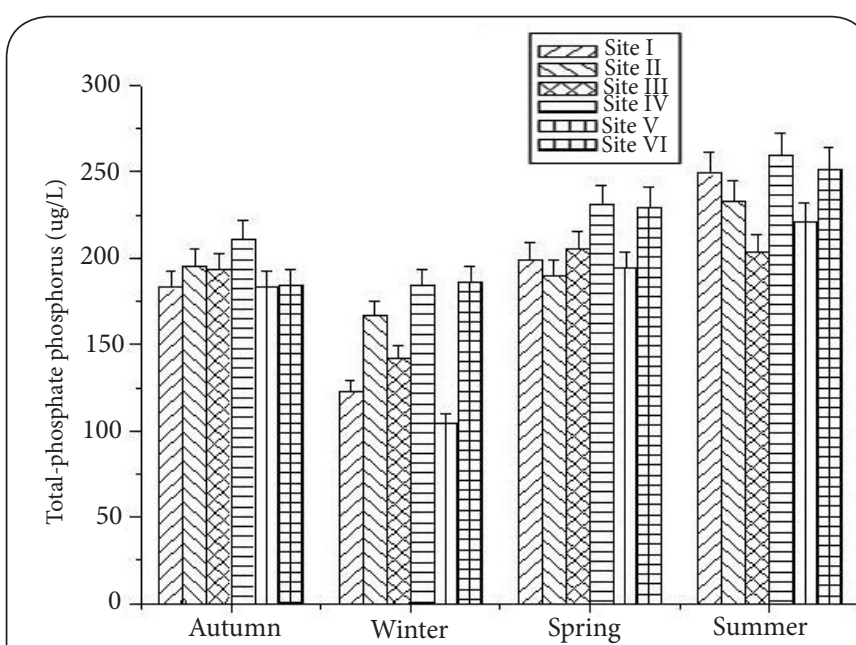

Figure 5. Seasonal variations of total-phosphate Phosphorus $(\mu \mathrm{g} / \mathrm{L})$ at six study sites.

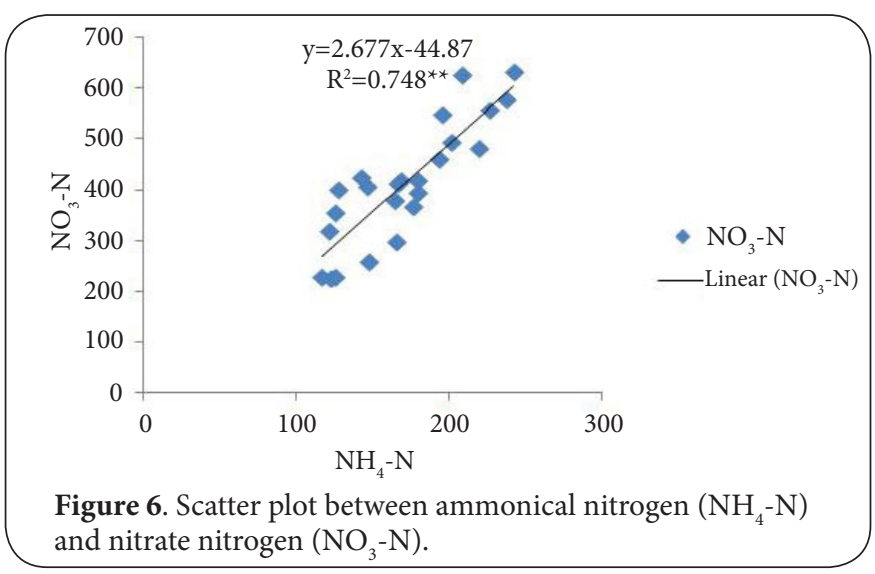

spring being attributable to combined result of nitrification at the mud water interface which eliminates any limiting effect of oxygen diffusion in the shallow lakes. The lower seasonal 


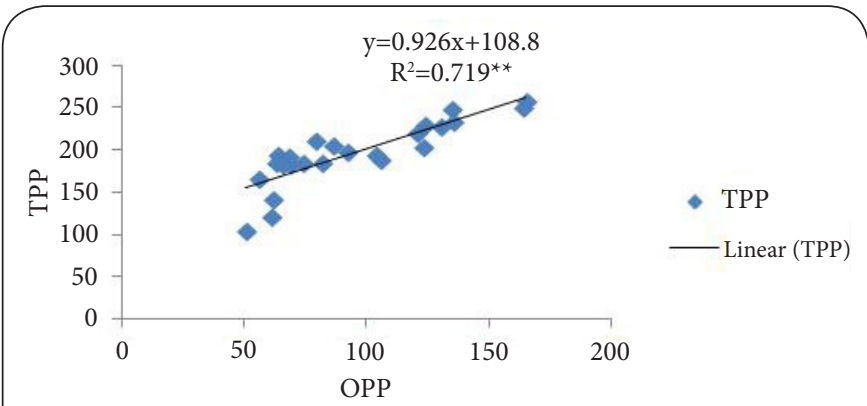

Figure 7. Scatter plot between total phosphorus (TPP) and ortho-phosphorus (OPP).

pattern of nitrate concentrations in growing seasonhas be devoted to lower leaching [59]. Further, increase in nitrogen concentration in winters can also be ascribed to increasing nitrogen fluxes from the sediment and the decrease in burial rates are considered as potential drivers of rising nitrate concentrations in lakes [60]. Furthermore, increase in primary productivity in summer results in lowering the nitrate concentrations while in winter the biological activity is lowered, resulting in higher peaks of nitrate nitrogen [61-63].

Seasonal variations in concentrations of both the forms of phosphorus in the present study reflect a significant influence by internal lake processes [64]. A strong and similar seasonality have been attributed to high retention capacity of shallow lakes throughout world $[65,66]$. This capacity of retainability of $P$ has been attributed to many factors, primary being the temperature simultaneously coupled with biological processes [64,67-70]. In summer the rise in temperature enhances the microbial activity which consequently results in the increase of diffusion process of $\mathrm{P}$ from the sediments to the overlying water column $[\mathbf{7 1}, \mathbf{7 2}]$. Besides diffusion process, change in $\mathrm{pH}$ and internal loading from sediments are considered to be the other plausible reasons [22,73-77]. Still further, seasonal variations in phytoplankton productivity are the other factors ascribed for higher peaks of P $[\mathbf{7 8 , 7 9 ]}$. Likewise, TPP concentrations, showing more pronounced summer peaks, are attributable to increase in trophic level [80].

Principal component analysis (PCA) has been used to distinguish waters of different qualities [81] by chemometrics methods used for the classification and comparison of diverse variables [82]. In the principal components the vector displacement are directly related, being proportional to the level/extent of the effect of the parameters measured and the sites they refer to. The highest principle component vector displacement among the sites was concluded to be the most polluted site (e.g., sites IV and VI-Figure 8). In the present study Component 1 showed $17.189 \%$ variation with respect to nitrate nitrogen $\left(\mathrm{NO}_{3}-\mathrm{N}\right)$, while Component 2 depicted highest variation of $81.701 \%$ with respect to ammonical nitrogen $\left(\mathrm{NH}_{4}-\mathrm{N}\right)$. Greater influence of $\mathrm{NH}_{4}-\mathrm{N}$ and $\mathrm{NO}_{3}-\mathrm{N}$ was reflected by large Eigen-vector displacement values, contributing 3.36724 (\%variance 84.181 ) and 0.542639 (\%variance 13.566)

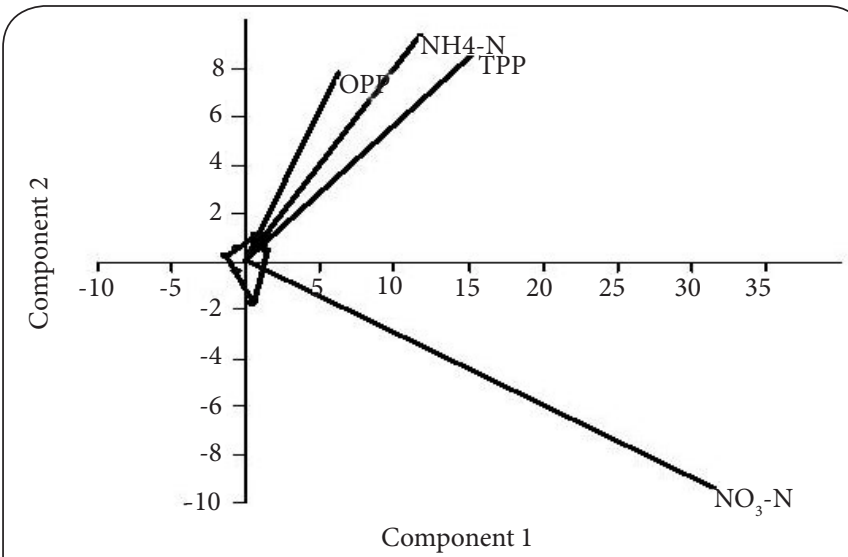

Figure 8. Principle component analyses of the mean water quality parameters during the study period.

respectively along the horizontal axis (Table 1). Similarity matrix was highest between $\mathrm{NH}_{4}-\mathrm{N}$ and TPP (92.9666\%), followed by OPP and $\mathrm{NH}_{4}-\mathrm{N}$ [71.4259\%] and OPP and TPP (65.094\%) in a decreasing order (Table 2).

Table 1. Eigen value and percent variance within parameters.

\begin{tabular}{lll}
\hline Parameter & Eigen value & \% variance \\
\hline $\mathrm{NH}_{4}-\mathrm{N}$ & 3.36724 & 84.181 \\
$\mathrm{NO}_{3}-\mathrm{N}$ & 0.542639 & 13.566 \\
$\mathrm{OPP}$ & 0.068808 & 1.7202 \\
$\mathrm{TPP}$ & 0.0213141 & 0.53285 \\
\hline
\end{tabular}

Table 2. Similarity Matrix among the parameters.

\begin{tabular}{llll}
\hline Parameters & $\mathrm{NO}_{3}-\mathrm{N}$ & OPP & \multicolumn{1}{c}{ TPP } \\
\hline $\mathrm{NH}_{4}-\mathrm{N}$ & 58.5729 & 71.4259 & 92.9666 \\
$\mathrm{NO}_{3}-\mathrm{N}$ & $*$ & 37.4081 & 64.5742 \\
$\mathrm{OPP}$ & $*$ & $*$ & 65.094 \\
$\mathrm{TPP}$ & $*$ & $*$ & $*$ \\
\hline
\end{tabular}

Bray-Curtis cluster analysis showed great similarity between sites IV and VI [0.97.8\%] due to high anthropogenic pressure from the immediate catchment. Contrarily, site I showed maximum dissimilarity with all the remaining sites during the entire study period because it is located near the inlet of the wetland. Sites II and III showed immediate similarity (Figure 9) as both the sites are located within the open water with good growth of macrophytes. Carpenter and Adams [83] and Pandit [84] are of the opinion that macrophyte beds in the lake may be useful in retaining nutrients by locking them up in their tissues, some of which could afterwards be removed by harvesting these aquatic plants.

\section{Conclusions}

Management of these wetland ecosystems is important as 


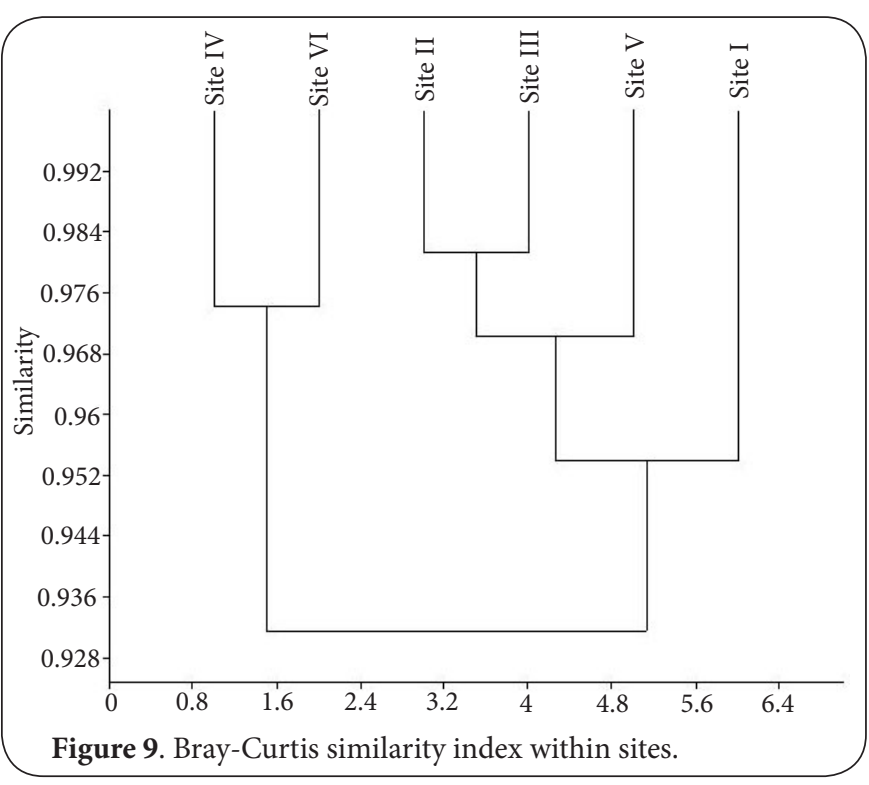

they endow with a variety of repairment mechanisms naturally and behave as biofilters to a certain critical levels. The need of hour is to limit loading of $\mathrm{N}$ and $\mathrm{P}$ to these natural ecosystems and to control eutrophication has been widely recognized although some researchers advocate that a policy of control P-only should be adopted for the well being of water-dwelling organisms and that of the water itself to prevent it for further degradation.

\section{Competing interests}

The authors declare that they have no competing interests.

\section{Authors' contributions}

\begin{tabular}{|l|c|c|c|}
\hline Authors' contributions & JAS & AKP & GMS \\
\hline Research concept and design & $\checkmark$ & $\checkmark$ & $\checkmark$ \\
\hline Collection and/or assembly of data & $\checkmark$ & -- & -- \\
\hline Data analysis and interpretation & $\checkmark$ & -- & -- \\
\hline Writing the article & $\checkmark$ & -- & -- \\
\hline Critical revision of the article & $\checkmark$ & $\checkmark$ & $\checkmark$ \\
\hline Final approval of article & $\checkmark$ & $\checkmark$ & $\checkmark$ \\
\hline Statistical analysis & $\checkmark$ & -- & -- \\
\hline
\end{tabular}

\section{Acknowledgement}

Thanks are due to the Director, Centre of Research for Development and Head, Environmental Science, University of Kashmir for providing necessary laboratory facilities.

\section{Publication history}

EIC: Rob Harrison, University of Washington, USA. Received: 17-Oct-2014 Final Revised: 06-Feb-2015 Accepted: 27-Mar-2015 Published: 08-Apr-2015

\section{References}

1. Sloey WE, Spangler, FL and Fetter CW. Management of freshwater wetlands for nutrient assimilation. Freshwater Wetlands: Ecological Processes and Management Potential (Ed. by R. E. Good, D. F. Whigham \& R. L. Simpson). Academic Press, New York. 1978.

2. Peterjohn WT and Correll DL. Nutrient Dynamics in an Agricultural Watershed: Observations on the Role of a Riparian Forest. Ecology.
1984; 65:1466-1475. | Article

3. Kemp GP and Day JW. Nutrient dynamics in a Louisiana swamp receiving agricultural runoff, in Cypress Swamps. 286-293. Ewel, KC and Odums HT eds: Gainesville, University of Florida Press, 1984.

4. Elder JF. Nitrogen and phosphorus speciation and flux in a large Florida River Wetland System. Water Resources Research, 1985; 21:724-732. | Article

5. Gosselink JG and Turner RE. The role of hydrology in freshwater wetland ecosystems, in Freshwater Wetlands, Good, RE, Whigham DF, and Simpson RL. eds: New York, Academic Press, 63. 1978.

6. Bayley SE, Zoltek J Jr, Hermann AJ, Dolan TJ and Tortora. L. Experimental manipulation of nutrients and water in a freshwater marsh: Effects on biomass, decomposition, and nutrient accumulation. Limnol. and Oceanogr. 1991; 30:500-512. I Pdf

7. Brix H. Wastewater treatment in construction: System design, removal processes, and treatment performance. 9-22. In: Constructed Wetlands for Water Quality Improvement. Lewis Publishers, 632p.GA. Moshiri ed. 1993.

8. Chapin, F.III. The mineral nutrition of wild plants. Annu. Rev. Ecol. Syst. I, 1980; 233-260. | Article

9. Shaver GR and Chapin FS III. Response to fertilization by various plant growth forms in an Alaskan tundra: Nutrient accumulation and growth. Ecology. 1980; 61:662-675. | Article

10. Millennium Ecosystem Assessment (MEA). Ecosystems and human wellbeing: wetlands and water synthesis. World Resources Institute, Washington. 2005; 80.

11. Mitsch WI, Gosselink IG Wetlands. Van Nostrand Reinhold, New York 539. 1986.

12. Pal $\mathrm{S}$ and Akoma OC. Water scarcity in wetland area within Kandi Block of West Bengal: A hydro-ecological assessment. Ethiop. J. Environ. Stud. Manag. 2009; 2:1-12. I Article

13. De Molenaar JG. Bemesting, waterhuishouding, intensivering in de landbouw en her natuurlijk milieu. Rijksinstituut voor Natuurbeheer, Leersum 1980.

14. Berendse, F. Organic matter accumulation and nitrogen mineralization during secondary succession in health and ecosystems. J. Ecol. 1990; 78:413-427.

15. Yan ND. Empirical prediction of crustacean zooplankton biomass in nutrient-poor Canadian Shield lakes. Can. J. Fish. Aquat. Sci. 1986; 43:788-796. | Article

16. Quiros R. The relationship between nitrate and ammonia concentrations in pelagic zone of lakes. Limnetica, 2003; 23: 37-50. | Pdf

17. Brown CD, Hoyer MV, Bachmann RW and Canfield Jr. DE Nutrientchlorophyll relationships: an evaluation of empirical nutrientchlorophyll models using Florida and north-temperate lake data. Can. J. Fish. Aquat. Sci. 2000; 57:1574-1583. | Pdf

18. Vorosmarty CJ, McIntyre PB, Gessner MO, Dudgeon D, Prusevich A, Green P, Glidden S, Bunn SE, Sullivan CA, Liermann CR and Davies PM. Global threats to human water security and river biodiversity. Nature. 2010; 467:555-61. | Article | PubMed

19. Cooke GD, Welch EB, Peterson SA and Newroth PR. Restoration and management of lakes and reservoirs. Lewis Publ Boca Raton, FL. 1993. I Article

20. Søndergaard M, Jensen JP and Jeppesen E. Internal phosphorus loading in shallow Danish lakes. Hydrobiologia, 1999; 408/409:145-152. | Article

21. Sondergaard $\mathrm{M}$, Jensen JP and Jeppesen $\mathrm{E}$. Role of sediment and internal loading of phosphorus in shallow lakes. Hydrobiologia. 2003; 506:135145. | Article

22. Søndergaard M, Phillips G, Hellsten S, Kolada A, Ecke F, Maemets H, Mjelde M, Azzella MM and Oggioni A. Maximum depth of submerged macrophytes in European lakes. Hydrobiologia. 2012. | Article

23. Newman, El. Phosphorus inputs to terrestrial ecosystems. Journal of Ecology, 1995; 83:713-726. | Article

24. Rabalais NN. Nitrogen in aquatic ecosystems. Ambio. 2002; 31:102-112. 


\section{| Article}

25. Layer K, Riede JO, Hildrew AG and Wood ward G. Food web structure and stability in 20 streams across a wide $\mathrm{pH}$ gradient. Adv. Ecol. Res. 2010; 42: 265-299. | Article

26. Layer K, Hildrew AG, Jenkins, GB, Riede J, Rossiter SJ, Townsend CR and Woodward G. Long-term dynamics of a well-characterised food web, four decades of acidification and recovery in the broadstone stream model system. Adv. Ecol. Res. 2011; 44:69-117. | Article

27. Ansar $A$ and Khad F. Eutrophication: An Ecological Vision. The Botanical Review. 2005; 71(4), 449-482. I Article

28. Gillies, RR, Box JB, Symanzik J and Rodemaker EJ. Effects of urbanization on the aquatic fauna of the line Creek Watershed, Arlanta. Remote Sens Environ. 2003; 86:411-422.

29. Palmer MA, Lettenmaier DP, Poff NL, Postel SL, Richter B and Warner R. Climate change and river ecosystems: protection and adaptation options. Environ Manage. 2009; 44:1053-68. | Article | PubMed

30. Viers $\mathrm{JH}$ and Rheinheimer DE. Freshwater conservation options for a changing climate in Californias Sierra Nevada. Mar Freshw Res. 2011; 62(3):266-278. | Article

31. Funk DE, Pullman E, Peterson K, Crill P and Billings W . Influenceof water table on carbon dioxide, carbon monoxide and methane flux from taiga bog microcosms. Glob Biogeochem. Cycles.1994; 8:271-278. | Article

32. Kraiem H. Biophysical and socio-economic impacts of climate change on wetlands in Mediterranean Proceedings of the Mediterranean Regional workshop on water, wasteland and climate change: Building Linkages for their integrated Management Athens, Greece. 2002.

33. Bayley SE, Wong AS and Thompson JE. Effects of agricultural encroachment and drought on wetlands and shallow lakes in the boreal transition zone of Canada. Wetlands. 2013; 33:17-28. | Article

34. Phillips B. Introduction. In A dicrectory of wetlands in Australia(2nd ed.), Australian Nature Conservation Agency, Canberra 1-16; 1996.

35. Gunatilaka A. 'Nutrient cycling in a freshwater reed marsh', Verhandlungen der Internationalen Vereinigung für Limnologie. 1991; 24:980-983.

36. Kadlec RH and Knight RL. Treatment Wetlands, CRC Press, New York, U.S.A. 1996; 893.

37. Kaul V and Zutshi DP. A study of aquatic and marshland vegetation of Srinagar lakes. Proc Nat/ Inst Sci India B. 1967; 33:111-128. | Pdf

38. Handoo JK. Ecological and Production Studies of Some Typical Wetlands of Kashmir. Ph.D Thesis, University of Kashmir, Srinagar. 1978; 141.

39. Handoo JK and Kaul V. Phytosociological and standing crop studies in wetlands of Kashmir. In: Gopal B, Whigam DF (eds) Wetlands: Ecology and Management, part1. National Institute of Ecology and International Scientific Publication, Jaipur. 1982; 187-197.

40. Kak AM. Aquatic and wetland vegetation of Kashmir Himalaya. J .Econ. Taxon Bot. 1990; 14:1-14.

41. Kaul S. Community architecture, biomass and production in some typical wetlands of Kashmir. Indian J. Ecol. 1982; 9:320-329.

42. Pandit AK. Biotic Factor and Food Chain Structure in Some Typical Wetlands of Kashmir. Ph.D. Thesis. University of Kashmir, Srinagar, J\&K. 1980.

43. Khan MA. Wetland biodiversity in the Kashmir Himalaya: Assessment and conservation strategies. Environmental Biodiversity and Conservation. (Khan MA ed.) APH Publishing, New Delhi, 2000. 69-93.

44. Rather SA, Bhat SA and Pandit AK. Water quality of Hokersar, a typical wetland of Kashmir. J. Res. Dev. 2001; 1:38-43.

45. Pandit AK and Kumar R. Comparative studies on ecology of Hokersar wetland, Kashmir: present and past. J. Himal. Ecol. Sustain. Dev. 2006; 1:73-81.

46. Kumar R. and Pandit A K. Physico-chemical characteristics of water in Hokerser wetland in Kashmir Himalaya. Pollution Research. 2007; 26 (4):73-79.

47. APHA 1998. Standard Methods for the Examination of Water and Waste Water, 20th Edition.

48. Wetzel RG and Likens GE. Limnological Analyses. 3 ed. Springer-Verlag,
New York. 2000; 429.

49. Maathuis FJ. Physiological functions of mineral macronutrients. Curr Opin Plant Biol. 2009; 12:250-8. I Article I PubMed

50. Vollenweider R. A. The scientific basis of lake and stream eutrophication, with particular reference to phosphorus and nitrogen as eutrophication factors. Tech. Rep. OECD, Paris,DAS/DS1/68, 27. 1968.

51. Hecky RE and Kilham P. Nutrient limitation of phytoplankton in freshwater and marine environments: $A$ review of recent evidence on the effects of enrichment. Limnol Oceanogr. 1988; 33:782-796. | Article

52. Reynolds CS and Davies PS. Sources and bioavailability of phosphorus fractions in freshwaters: a British perspective. Biol Rev Camb Philos Soc. 2001; 76:27-64. | Article | PubMed

53. Moss B, Jeppesen E, Søndergaard M, Lauridsen TL and Liu Z. Nitrogen, macrophytes, shallow lakes and nutrient limitation: Resolution of a current controversy? Hydrobiologia. 2012. | Article

54. Crisman TL, Beaver JR, Jones JK, Keller AE, Neugaard AG and Nilakantan V. Historical Assessment of Cultural Eutrophication in Lake Weir, Florida. Department of Environmental Engineering Sciences, University of Florida, Gainesville and St. John's River Water Management District, Palatka, Florida. 1992; 22.

55. Yanamadala V. Calcium carbonate phosphate binding ion exchange filtration and accelerated denitrification improve public health standards and combat eutrophication in aquatic ecosystems. Water Environ Res. 2005; 77:3003-12. | Article | PubMed Abstract | PubMed Full Text

56. Lewis WM, Wurtsbaugh WA and Paerl HW. Rationale for control of anthropogenic nitrogen and phosphorus to reduce eutrophication of inland waters. Environ Sci Technol. 2011; 45:10300-5. | Article | PubMed

57. Wetzel RG. Limnology of Lake and River Ecosystems. Third Edition. Academic Press, San Diego, CA. 1006; 2001.

58. Quiros R. Factors related to variance of residuals in chlorophyll total phosphorus regressions in lakes and reservoirs of Argentina. Hydrobiologia. 1990; 200/201:343-355. | Article

59. Rogora M, Arisci S and Marchetto A. The role of nitrogen deposition in the recent nitrate decline in lakes and rivers in Northern Italy. Sci Total Environ. 2012; 417-418:214-23. | Article | PubMed

60. Finlay JC, Sterner RW and Kumar S. Isotopic evidence for in-lake production of accumulating nitrate in Lake Superior. Ecol Appl. 2007; 17:2323-32. | Article | PubMed

61. Brockmann U, Billen G and Gieskes WWC. North Sea nutrients and eutrophication. In: North Sea Pollution. Salomons, W. Bayne, BL, Duursma, E.K., Forstner, U. eds.). Springer Verlag, Berlin. 1988; 348-389. | Article

62. Prandle D, Hydes DJ, Jarvis J and McManus J. The seasonal cycles of temperature, salinity, nutrients and suspended sediment in the Southern North Sea in 1988 and 1989. Estuarine, Coastal and Shelf Science, 1997; 45:669-680. | Article

63. Gentilhomme $V$ and Lizon F. Seasonal cycle of nitrogen and phytoplankton biomass in a well-mixed coastal system (Eastern English Channel). Hydrobiologia, 1997; 361:191-199. | Article

64. Jeppesen E, Jensen JP, Sødergaard M, Lauridsen T and Landkildehus F. Trophic structure, species richness and biodiversity in Danish lakes: Changes along a phosphorus gradient. Freshwater Biology. 2000; 45:201-218. | Article

65. Ryding SO. Reversibility of man-induced eutrophication. Experiences of a lake recovery study in Sweden. Int. Revue ges. Hydrobiol. 1981; 66:449-503. | Article

66. Van der Molen DT. A simple, dynamic model for the sim- ulation of the release of phosphorus from sediments in shallow, eutrophic systems. Wat. Res. 1991; 25:737-744. | Article

67. Jensen HS and Andersen $F \varnothing$. Importance of temperature, nitrate and $\mathrm{pH}$ for phosphate release from aerobic sediments of four shallow, eutrophic lakes. Limnol. Oceanogr. 1992; 3:577-589. | Pdf

68. Jeppesen E, Jensen JP, Søndergaard $M$, Lauridsen T, Pedersen $L J$ and Jensen L. Top-down control in freshwater lakes: The role of nutrient state, submerged macrophytes and water depth. Hydrobiologia. 1997; 
Shah et al. Journal of Environmental Engineering \& Ecological Science 2015, http://www.hoajonline.com/journals/pdf/2050-1323-4-1.pdf

342/343:151-164. | Article

69. Nixdorf B and Deneke R. Why 'very shallow' lakes are more successful opposing reduced nutrient loads. Hydrobiologia. 1997; 343:269-284. I Article

70. Boers PCM, Van Raaphorst W and Van der. Molen TD Phosphorus retention in sediments. Wat. Sci. Tech. 1998; 27:31-39. | Article

71. Bostrom B, Jansson $\mathrm{M}$ and Forsberg C. Phosphorus release from lake sediments. Arch. Hydrobiol. 1982; 5-59.

72. Maassen S, Uhlmann D and Roske I. Sediment and pore water composition as a basis for the trophic evaluation of standing waters. Hydrobiologia. 2005; 543:55-70. | Article

73. Barbiero RP and Kann J. The importance of benthic recruitment to the population development of Aphanizomenon flosaquae and internal loading in a shallow lake. J Plankton Res. 1994; 16:1581-1588. | Article

74. Hoorman J, Hone T, Sudman T. Jr, Dirksen T, lles J and Islam KR. Agricultural impacts on lake and stream water quality in Grand Lake St. Marys, western Ohio. Water Air Soil Pollu. 2008; 193:309-322. | Article

75. Boros G, Tatrai, I, Gyorgy Al, Vari A and Nagy AS. Changes in internal phosphorus loading and fish population as possible causes of water quality decline in a shallow, biomanipulated lake. Int. Rev. Hydrobiol. 2009; 94:326-337. | Article

76. Spears BM, Carvalho L, Perkins R, Kirika A and Paterson DM. Long-term variation and regulation of internal phosphorus loading in Loch Leven. Hydrobiologia. 2012; 681:23-33. | Article

77. Filbrun, JE, Conroy JD and Culver DA. Understanding seasonal phosphorus dynamics to guide effective management of shallow, hypereutrophic Grand Lake St. Marys, Ohio . Lake and Reservoir Management. 2013; 29:165-178. | Article

78. Søndergaard M. Phosphorus release from a hypertrophic lake sediment: Experiments with intact sediment cores in a continuous flow system. Arch. Hydrobiol. 1989; 116:45-59.

79. Istvanovics $V$ and Pettersson K. Phosphorus release in relation to composition and isotopic exchangeability of sediment phosphorus. Arch. Hydrobiol. Spec. Issues Advanc. Limnol. 1998; 51:91-104.

80. Xie P. Biological mechanisms driving the seasonal changes in the internal loading of phosphorus in shallow lakes. Science in China: Series D Earth Sciences. 2006; 49:14-27. | Article

81. Brodnjak-Voncina D, Dobcnik D, Novic M and Zpan J. Chemometric characterization of the quality of river water. Analytica Chimica Acta. 2002; 462:87-100. I Article

82. Massart DL, Vandeginste, BGM, Buydens LMC, De Jong S, Lervi PJ and Smeyers-Verbeke, J. In: Handbook of Chemometrics and Qualimetrics: (BGM, Vandeginste, Puten SC eds.) Part A. Elsevier, Amsterdam. 1997; 867.

83. Carpenter SR and Adams MS. Environmental impacts of mechanical harvesting of submerged vascular plants. Institute for Environmental Studies, University of Wisconsin. Report No. 77; 1977.

84. Pandit AK. Role of macrophytes in aquatic ecosystems and management of freshwater resources. Journal of Environmental Management (London). 1984; 18:73-88. | Article

\section{Citation:}

Shah JA, Pandit AK and Shah GM. Dynamics of key plant nutrients (N \& P) in hokersar, a typical wetland of Kashmir Himalaya, India. J Environ Eng Ecol Sci. 2015; 4:1.

http://dx.doi.org/10.7243/2050-1323-4-1 